степени канд. пед. наук / О. И. Митрош. - Минск, 1993. - 18 с. 13. П'ятницькаПозднякова I. С. Основи наукових досліджень у вищій школі / I. С. П'ятницькаПозднякова. - К. : Центр навч. літ-ри, 2003. - 116 с. 14. Скаткин М. Н. Методология и методика педагогических исследований (в помощь начинающему исследователю) / М. Н. Скаткин. - М. : Педагогика, 1986. - 150 с. 15. Цехмістрова Г. С. Основи наукових досліджень: [навч. посіб.] / Г. С. Цехмістрова. - К. : Слово, 2003. - 240 с.

УДК 371. 134:373.3

Наталя Іванець

\title{
РОЛЬ ОСОБИСТОСТІ ВЧИТЕЛЯ В МУЛЬТИКУЛЬТУРНОМУ ВИХОВАННІ УЧНІВ ПОЧАТКОВОЇ ШКОЛИ
}

Іванець Н. В. Роль особистості вчителя в мультикультурному вихованні учнів початкової школи.

У статті розкрито значення поняття «мультикультурна освіта», викладено основні характеристики мультикультурної компетентності сучасного вчителя, які сприятимуть формуванню мультикультурної поведінки у школярів під час навчальновиховного процесу.

Ключові слова: мультикультурність, мультикультурна компетентність, мультикультурна особистість, мультикультурна освіта, мультикультурне виховання, мультикультурна поведінка.

Иванец Н. В. Роль личности учителя в мультикультурном воспитании учеников начальной школы.

В статье раскрыто значение понятия «мультикультурное образование», изложены основные характеристики мультикультурной компетентности современного учителя, способствующие формированию мультикультурного поведения у школьников во время учебно-воспитательного процесса.

Ключевые слова: мультикультурность, мультикультурная компетентность, мультикультурная личность, мультикультурное образование, мультикультурное воспитание, мультикультурное поведение.

Ivanets N. V. A role of personality of teacher is in multicultural education of pupils of primary school.

In the article the meaning of the notion «multicultural competence» is revealed, the main characteristics of the future teacher's multicultural competence, which promote the formation of pupils' multicultural behavior during the educational process are stated.

Key words: multiculturalism, multicultural competence, multicultural personality, multicultural education, multicultural upbringing, multicultural conducting.

Одним із найважливіших завдань вищої педагогічної школи $є$ підготовка майбутніх учителів до реалізації ідей мультикультурної освіти в навчально-виховному процесі загальноосвітньої школи. Тому що однією 3 актуальних проблем сучасної школи є мультикультурне виховання підростаючого покоління, в основі якого лежить етнічна культура $з$ іiї педагогічними можливостями. На наш погляд, його виконання передбачає формування мультикультурної компетентності сучасного вчителя, під якою розуміють сукупність певних якостей особистості 3 високим рівнем інтелектуальних знань, професійно-педагогічних умінь і навичок, завдяки яким він 
може професійно працювати в умовах поліетнічного й полікультурного суспільства.

Упровадження мультикультурної дидактичної моделі варто розпочинати 3 тлумачення самого поняття «мультикультурна освіта», із з'ясування настанов учителів на дослідження того, як це ставлення впливає на зміст їхньої роботи, нарешті- навичок відкритого діалогу 3 учнями в умовах різноманіття їх соціокультурного досвіду. В учнів є права на повагу й увагу до їх індивідуальних відмінностей.

Отже, мультикультурна освіта - це освіта, що створює рівні для всіх етносів можливості реалізації своїх культурних потреб, прилучає молодь до культурних i моральних цінностей інших країн i народів. Саме в мультикультурній освіті реалізується повною мірою принцип діалогу та взаємодії культур (Ю. Бочарова, А. Куропятник, Г. Палаткіна, С. Петрова, А. Шафікова та інші). Мультикультурна освіта формує мультикультурну особистість, що визнає культурний плюралізм i активне сприяння йому, що прагне захищати національно-культурне різноманіття [3].

У структурі мультикультурної компетентності вчителя можна виокремити три основні складники:

- аксіологічний, що є системою загальнолюдських і національних цінностей;

- особистісний, системоутворювальними елементами якого $є$ гуманізм, громадянська свідомість, національна самосвідомість і толерантність;

- професійний, що складається 3 культурологічних знань, а також загальнопедагогічних знань і вмінь.

Аналіз останніх публікацій з проблеми показав, що дослідженню особливостей мультикультурної освіти приділяється належна увага, зокрема теоретикометодологічні засади обгрунтовуються в роботах сучасних науковців: Р. Агаддуліна, О. Гривої, О. Гуренко, М. Лещенко, Н. Миропольської. Полікультурне виховання як соціокультурний феномен представлено у працях I. Беха, О. Сухомлинської. Проблему мультикультурної освіти досліджували зарубіжні науковці: С. Абрамова, О. Аракелян, Н. Байчекуєв, I. Васютенкова, М. Воловікова, О. Гукаленко, О. Джуринський, П. Сисоєв, Дж. Бенкс, Ж. Гей, М. Гібсон, К. Грант, С. Нієто, Д. Гілборн, Дж. Уайт, Дж. Хартлі, М. Вайнберг, В. Міттер, Т. Рюлькер, Дж. Хофф та інші.

Основоположником теоретичних ідей мультикультурної освіти був ще Я. Коменський, який обгрунтував програму універсального виховання. Вихідним пунктом такого виховання був процес формування в людини 3 дитинства умінь жити в гармонії $з$ іншими культурами, виконувати взаємні обов'язки, поважати і любити людей.

Mema cmammi- визначити рівень сформованості мультикультурної компетентності майбутніх учителів, розкрити роль особистості вчителя в умовах мультикультурного виховного середовища.

Нині майже кожен регіон нашої країни можна назвати мультикультурним. Уважається, що головним складником мультикультурного освітнього простору повинні бути, насамперед мультикультурна школа та іiі педагогіка. Мультикультурність нашої країни й інтегративні завдання формування українського народу вимагають обов'язкового втілення в соціокультурних характеристиках загального виховного ідеалу. Він також повинен бути відображений у спільних цілях і завданнях сучасної школи на всіх іiі ланках, у змісті навчання i виховання i найголовніше - в підготовці педагогічних кадрів для його реалізації.

На наш погляд, у мультикультурному вихованні доцільною є така послідовність: 
- національне виховання, що розуміється як прищеплення любові і поваги до свого народу, гордості за його культурно-історичні досягнення;

- знайомство дітей з людьми найближчого національного оточення, формування доброзичливого ставлення до однолітків і дорослих сусідніх національностей на основі долучення до звичаїв і традицій сусідніх народів;

- повідомлення знань про етнічну самобутність віддалених народів і формування емоційно-позитивного ставлення до національного різноманіття планети.

Як працювати вчителю, здійснювати мультикультурну освіту, коли в класі одночасно навчаються представники кількох національностей? Яку допомогу можна надати вчителям, ураховуючи те, що вони виховані і сформовані на основі власних національних традицій?

Одна 3 найважливіших функцій школи - навчити людей жити разом, допомогти їм перетворити наявну взаємозалежність держав і етносів на свідому солідарність. Саме вчитель повинен бути особливо уважним до культурних відмінностей своєї школи, і особливо класу, у якому він працює: постійно спостерігати, досліджувати, оцінювати - у тому числі і свою реакцію на пережите й побачене.

Учитель повинен прагнути розвинути в себе такі вміння:

- вивчати психологію расизму, ксенофобії, дискримінації, механізми створення стереотипів;

- розуміти і приймати багатокультурну ідентичності школярів;

- вивчати культурну атмосферу у класі задля визначення рівня толерантності культурних відмінностей;

- створювати атмосферу толерантності, прийняття, поваги та затвердження культурних відмінностей у класі;

- розуміти, що проблеми дискримінації, ненависті, насильства успішно розв'язуються тільки у взаємодії з батьками, соціальними працівниками й широкою громадськістю;

- аналізувати власні культурні упередження і стереотипи й позбуватися них;

- критично й рефлексивно мислити;

- творчо, без застосування насилля, вирішувати конфлікти і вчити цього школярів;

- допомагати школярам визначити свою культурну ідентичність [1].

У концепції модернізації освіти наголошується на необхідності значного розширення масштабів мультикультурної взаємодії, у зв'язку 3 чим особливу важливість набувають чинники міжкультурної комунікабельності і толерантності, а одним iз найважливіших завдань мультикультурного виховання визначається спрямованість на загальнолюдські цінності, виховання гідного громадянина своєї держави та рівною мірою - громадянина світу.

Зрозуміло, що задля розвитку особистої мультикультурності вчителю необхідно мати й інші вміння та знання з галузі педагогіки, політики, етнології, антропології, психології, конфліктології, соціології та філософії.

Визначальною якістю вчителя є гуманність, тобто ставлення до людини як найвищої цінності на землі, вияв цього ставлення в конкретних справах і вчинках. Гуманні стосунки складаються з інтересу до особистості учня, допомоги йому, поваги до його думки. Учитель - завжди активна, творча особистість. Пробуджувати інтереси, вести учнів за собою може тільки людина з розвиненою волею, де особистій активності відводиться вирішальне місце. Педагог-зразок для наслідування, спонукає учнів слідувати за ним, рівнятися на доступний для наслідування зразок [1]. 
Наведемо чотири ознаки, які характеризують учителя, готового до мультикультурного виховання:

1. Учитель сам повинен володіти тими рисами характеру, які він хоче виховати у своїх учнів.

Учитель своїм складом мислення і способом життя повинен довести, що в нього $\epsilon$ риси ідеального учня. Він повинен виявляти вдячність своїм учителям; володіти яскраво вираженою і щирою спрагою знання, а також мати яскраво виражене бажання передати іншим те, чого навчився сам.

2. Учитель повинен уміти побачити потенціал свого учня (або повірити в нього) $\mathrm{i}$ розкрити цей потенціал, допомогти учневі реалізувати його. Учитель вірить у здатність учня вчитися. Справжній учитель - це той, хто впевнений, що може змінити учня.

Учитель повинен уміти вчити і виховувати відповідно до здібностей учня. Деякі методи і прийоми будуть більш ефективні для одних, ніж для інших. Тому той, хто спостерігає за стосунками вчителя й учня з боку, може помітити, що вчитель дискримінує одних і виявляє своє позитивне ставлення до інших учнів, що робити суворо заборонено. Проте справжній учитель знає (або повинен знати) рівень розуміння свого учня i, співвідносячи, використовує найбільш ефективні прийоми, щоб роз'яснити учневі суть предмета.

3. Учитель повинен спонукати учня розвивати здатність мислити самостійно i бути самостійним. Самостійним у тому сенсі, щоб навчитися вчитися, спостерігати, сумніватися і ставити питання, діяти і жити, спираючись на те, чого його навчив учитель. Завдяки присутності вчителя учень навчається співчувати.

4. Якщо вчитель приймає учня, це сприяє з боку останнього вияву довіри на все життя. Це означає, що з боку вчителя повинна бути беззастережна любов до учнів. Це дбайливе ставлення до учнів насамперед виявляється у справах, а не в словах. Учителів турбує не тільки освіта його учнів, але й їх життя загалом [1].

Діяльність учителя повинна бути спрямованою на виховання в учнів толерантного ставлення до багатоманітності культур. Учителю слід брати до уваги і використовувати у процесі навчання гнучкість дитячого мислення і подавати дітям думку, що «називати речі і робити роботу можна по-різному» [1].

Лексика вчителя не повинна містити соціокультурних упереджень стосовно різноманіття культур (висловлювань на кшталт «тупий, як чукча» тощо). Мова, тексти і культура перебувають у постійній взаємодії між собою. Кожен акт комунікаціїкультурна подія. Культура визначає структуру, процес і зміст комунікації [1].

До змісту своєї педагогічної діяльністі вчитель повинен також включати свій соціокультурний досвід, відрефлексувавши його i, систематично конструюючи ті фрагменти, які слід було б внести до навчального процесу, передавати їх школярам. Він також спонукає учнів до розкриття фактів власного досвіду - до обміну досвідом [4].

Отже, роль особистості вчителя в мультикультурному вихованні учнів початкової школи полягає в необхідності активно розвивати міжетнічні контакти між учнями різних національностей та учнями з різних національних шкіл, як у процесі основного навчання, так і в центрах позашкільної роботи.

Важливо навчити учнів пізнавати і розуміти довкілля, виховати в них почуття симпатії, співпереживання, солідарності, терпимості, толерантності. 3 цією метою зміст i форми роботи навчальних закладів слід осучаснювати технологіями полікультурної освіти та особистісно зорієнтованої взаємодії. 
Отже, формування мультикультурної особистості учнів початкової школи становить навчально-виховний процес, що спирається на специфічні зміст і технології освіти i спрямований на набуття ними цінностей, знань, умінь i навичок мультикультурної освіти, їх творче використання у своїй діяльності й самовихованні себе як особистості, самосвідомого громадянина, який $\epsilon$ запорукою духовно розвиненого суспільства.

\section{Література}

1. Агаддулин Р. P. Поликультурная профессиональная компетентность современного учителя / Р. Р. Агаддулин // Проблеми сучасної педагогічної освіти. К. : Пед. преса, 2003. - С. 12-17. 2. Балицька I. В. Мультикультурное образование в США, Канаде и Австралии : автореф. дис. на соискание ученой ступени д-ра пед. наук : 13.00.01. / Балицкая И. В. - М, 2009. - 40 с. 3. Джуринский О. Н. Педагогика межнационального общения: Поликультурное воспитание в России и зарубежом: [учеб. пособ. для вузов]/ О.Н. Джуринский. - М. : Сфера, 2007. - 224 с. 4. Трасберг К. Мультикультурное образование : развитие идей и поиск путей их реализации в современном мире / К. Трансберг; под. ред. Л. Васильченко. - Тарту, 2004. - С. 7-12.

Лідія Коростіль

\section{СТАН ГОТОВНОСТІ ВЧИТЕЛІВ СІЛЬСЬКОЇ ШКОЛИ ДО ПРОФЕСІЙНОЇ САМООСВІТНЬОЇ ДІЯЛЬНОСТІ}

Коростіль Л. А. Стан готовності вчителів сільської школи до професійної самоосвітньої діяльності.

У статті розглядаються особливості самоосвіти вчителів сільської школи, висвітлюються результати проведеного самодіагностування стану готовності вчителів різних вікових категорій до самоосвітньої діяльності, зроблено порівняння та доведено, що здатність до самоосвіти у процесі практичної діяльності вчителя не тільки розвивається і поглиблюється, а й вигасає, змінює пріоритети в ії змісті. Це пов'язано з віковими змінами інтересів і можливостей людини, а також професійним вигоранням учителя.

Ключові слова: вчитель сільської школи, професійна самоосвіта, професійна самоосвіта вчителя сільської школи, готовність до самоосвітньої діяльності, самодіагностування, професійне вигорання.

Коростіль Л. А. Состояние готовности учителей сельской школы к профессиональной самообразовательной деятельности.

В статье рассматриваются особенности самообразования учителей сельской школы, освещаются результаты проведенного самодиагностирования состояния готовности учителей разных возрастных категорий к самообразовательной деятельности, сделаны сравнения и доказано, что способность к самообразованию в процессе практической деятельности учителя не только развивается и углубляется, а и угасает, меняет приоритеты в ее содержании, что связано с возрастными изменениями интересов и возможностей человека, а также профессиональным выгоранием учителя.

Ключевые слова: учитель сельской школы, профессиональное самообразование, профессиональное самообразование учителей сельской школы, готовность к самообразовательной деятельности, самодиагностирование, профессиональное выгорание. 